УДК 664.034

\title{
MANUFACTURE OF GROATS AND FLAKED PRODUCTS BY PROCESSING OF NAKED OATS GRAIN AND HULL-LESS BARLEY
}

\author{
S. Sots, I. Kustov, Y. Kuzmenko \\ Odessa National Academy of Food Technologies
}

\begin{tabular}{l}
\hline \multicolumn{1}{c}{ Key words: } \\
naked oats, \\
hulles barley, \\
technological properties, \\
increase of nutritional \\
value, \\
simplification of \\
technological process \\
\hline \multicolumn{1}{c}{ Article history: } \\
Received 15.04.2020 \\
Received in revised form \\
10.05.2020 \\
Accepted 25.05 .2020 \\
\hline
\end{tabular}

Corresponding author: kuzmenko.y89@gmail.com

In the modern structure of nutrition human cereal products take about $20 \ldots 30 \%$ of the total consumption of grain products.

The structure of processing hull-less barley and naked oats in combined products was developed. Due to differences in the characteristics especially the form of grain primary processing of hull-less barley and naked oats are carried out without fractionation on two parallel lines. As a result of pearling of hullless barley and naked oats grain formed a mixture consisting of whole pearled groats, particles of crushed kernels and husking bran. For its separation and removal of whole pearled groats the mixture at the first stage is sent to plansifter where conduct removal of particles of crushed kernels and husking bran. On the next stage at producing of mixed groats conduct mixing of pearled groats of hull-less barley and naked oats in given mass fraction and send mixture to water heat treatment stage. For the production of a mixture of flakes whole pearled groats after pearling sent to water heat treatment. This stage in the production of flakes carried out by a combined structure of cold and hot conditioning the main purpose is to provide plastic properties of groats. Flaking conducted at flaking machine on ribbed rolls which provides the formation of microcracks on the surface of flaked groats and allow accelerate cooking time of the resulting product. To removed particles of crushed kernels and husking bran which are formed in small quantities at flaking mixture of flaked groats sieved. Flaked groats dried at belt dryer at temperature of drying agent $40-60^{\circ} \mathrm{C}$ to moisture content of $13-14 \%$. At this use as raw materials of hull-less barley and naked oats at the recommended modes can increase yield of pearled and flaked groats at 1.5-1.7 times in compared to processing of conventional varieties. Resulting products through the use of soft modes of pearling and water heat treatment characterized by high nutritional value - have a greater proportion of protein and $\beta$-glucans.

DOI: $10.24263 / 2225-2916-2020-27-4$

(C) С. М. Соц, І.О. Кустов, Ю. Я. Кузьменко, 2020 


\title{
ВИРОБНИЦТВО КРУП І ПЛЮЩЕНИХ ПРОДУКТІВ ПРИ ПЕРЕРОБЦІ ЗЕРНА ГОЛОЗЕРНОГО ВІВСА ТА ГОЛОЗЕРНОГО ЯЧМЕНЮ
}

\author{
С. М. Соц, канд. техн. наук \\ І. О. Кустов, канд. техн. наук \\ Ю. Я. Кузьменко, канд. техн. наук \\ Одеська національна академія харчових технологій
}

У статmі розглянуто основні переваги голозерного зерна вівса та ячменю над традиційними формами, що обумовлює перегляд та наукове обгрунтування структури, режимів, технологічного процесу з розширенням асортименту та можливістю виробництва продуктів з підвищеною харчовою цінністю.

Розроблено структурну схему переробки голозерного вівса та голозерного ячменю в комбіновані крупи та плющені продукти, яка включає очищення зерна від домішок, водно-теплову обробку зерна, шліфування, сортування продуктів шліфування, водно-теплову обробку крупи, змішування, плющення, підсушування та контроль готової продукції.

Встановлено, що застосування голозерного вівса та голозерного ячменю при рекомендованих режимах дає змогу збільшити вихід шліфованого та плющеного ядра в 1,5-1,7 раза порівняно з переробкою плівчастих культур.

Ключові слова: голозерний овес, голозерний ячмінь, технологія виробництва, підвищення харчової цінності, спрощення технологічного процесу.

Постановка проблеми. Круп'яна галузь харчової промисловості належить до соціально значущих галузей агропромислового комплексу. Стан і розвиток круп'яної промисловості держави є одним із визначальних факторів добробуту, працездатності та здоров'я ії населення.

Аналіз сучасного стану вітчизняного виробництва круп і круп'яних продуктів вказує на відставання вітчизняних технологій від сучасних зарубіжних аналогів.

Існуючі технології не дають змогу отримувати при переробці вівса високий вихід готової продукції, що не перевищує 55-65\% навіть при застосуванні найбільш сучасних плівкових сортів вівса із покращеними властивостями. Також виникає необхідність складування, зберігання та утилізації значної кількості лузги, кількість якої, залежно від сортових особливостей зерна, що переробляється, може сягати $20-40 \%$ [1; 2]. Технологічні процеси переробки плівчастого вівса є одними 3 найбільш складних у круп'яному виробництві, адже включають водно-теплову обробку методом гарячого кондиціювання, лущення на декількох системах, сортування продуктів лущення, складне круповідділення, шліфування тощо. Все це призводить до значної енерговитратності технології та необхідності значних виробничих площ для ii реалізації. На різних етапах переробки, особливо при пропарюванні зерна, відбувається зменшення харчової цінності зерна та, відповідно, продуктів його переробки (зменшення масової частки білка, крохмалю, вітамінів тощо). При лущенні та шліфуванні зерна утворюється значна кількість побічних продуктів у вигляді борошенця та частинок подрібненого ядра (15-35\%), які формуються за рахунок зовнішніх і внутрішніх частин вівсяного ядра та зменшують масову частку білка, $\beta$-глюканів, вітамінів, мінералів тощо, що у сукупності з невисокими значеннями виходу готової 
продукції дає змогу говорити про невисоку ефективність існуючих технологій для виробництва сучасно орієнтованих продуктів харчування.

На основі аналізу існуючих технологій переробки ячменю можна зробити висновок, що виробництво ячмінних продуктів потребує використання багатьох технологічних процесів, проте вихід круп перлових не перевищує 45\%, круп'ячних $65 \%[1-3]$.

У багатьох країнах світу спостерігається тенденція розширення асортименту круп'яних продуктів. Розширення асортименту та висока ефективність переробки досягається за рахунок використання нових круп'яних культур. Поява більш ефективного сучасного обладнання призводить до того, що круп'яні підприємства все більше орієнтуються на зернові та бобові культури, які ще $10-15$ років тому не вважалися перспективними для виробництва круп і використовувалися більшою мірою на кормові цілі.

Аналіз основних досліджень і публікацій. Розробка технологій нових продуктів, в основу яких покладено раціональне використання природного потенціалу зерна, зокрема збільшення харчової цінності кінцевого продукту для організму людини, є сучасним світовим напрямком розвитку зернопереробної промисловості. До таких продуктів можна віднести продукти, вироблені на зерновій основі, які здатні не тільки збагачувати організм людини білками, жирами, вуглеводами, їхніми складовими та іншими мікро- та мікроелементами, але й виконують важливі для організму функції, тобто здатні сприяти роботі основних його систем, виводити шкідливі речовини тощо. Л. І. Бутенко та Л. В. Лігай [4] відзначають, що, як правило, основою для виробництва продуктів з функціональними властивостями $є$ пластівці, вироблені із зернових культур, які володіють достатньо високою харчовою цінністю. Сучасним напрямком створення продуктів функціонального призначення $\epsilon$ розробка рецептур продуктів, до складу яких входить декілька зернових культур сумішей злакових пластівців, круп, борошна тощо. Н. Карвовськи та Р. Фераро [5] запропонували спосіб виробництва зернових пластівців з трьох зернових культур, який передбачає можливість використання як компонентів пшениці, жита, вівса, ячменю, рису, кукурудзи та гречки. Спосіб передбачає різання, змішування, зволожування, пропарювання, темперування, плющення та сушіння.

К. Сеппо та інші [6] розробили технологію для виробництва продукту збагаченого $\beta$-глюканами, яка передбачає використання голозерного вівса (або лущеного ядра вівса). Продукт являє собою тонко здрібнену фракцію вівсяного борошна $\mathrm{i}$ може використовуватися в зернових сніданках, готових до споживання продуктах тощо. Технологічний процес виробництва передбачає подрібнення вівсяного зерна на двох системах, після кожного здрібнювання передбачена своя сортувальна система. Перша сортувальна система забезпечує розділення продуктів здрібнювання на дві фракції: грубу (вміщує оболонкові частини) та попередньо збагачену більш тонку фракцію (вміщує частини ендосперму разом із субалейроновим шаром), яку направляють на повторне здрібнювання. Друга сортувальна система забезпечує розділення продуктів здрібнювання на дві фракції, за винятком того, що отримана на цьому етапі груба фракція являє собою готовий продукт.

Відомий спосіб виробництва багатокомпонентних зернових пластівців [7; 8], що передбачає використання крупи рисової, гречаної та зародків пшениці. Технологічний процес включає очищення та підготовку компонентів, пропарювання суміші при тиску пари 0,05-0,10 МПа, плющення та підсушування пластівців до вологості 
$12-14 \%$. Кінцевий продукт вміщує 50-60\% зародків пшениці, $20-30 \%$ рисової крупи та до 20\% гречаної крупи. Як зазначають автори, такий продукт володіє підвищеною харчовою цінністю, має високий вміст білка, вітамінів і харчових волокон.

В Україні сьогодні також підвищується попит на виробництво комбінованих зернових продуктів із використанням сумішей декількох видів пластівців, борошна та круп, які володіють високою харчовою цінністю. Аналіз проведених в нашій країні досліджень показує, що основою для їх виробництва $є$ крупи (вівсяні неподрібнені крупи, перлові, рисові шліфовані, гречані крупи тощо) або плющені продукти, вироблені з традиційної сировини при застосуванні існуючих технологій. Незважаючи на те, що, як правило, вихідна сировина володіє високою харчовою та поживною цінністю, в процесі ії переробки в круп'яні продукти втрачається значна кількість білка, вітамінів, мікро- та мікроелементів, жирів. Це призводить до того, що використання традиційних круп або пластівців для створення на їх основі продуктів із підвищеною харчовою цінністю не дає змоги отримати кінцеві продукти 3 підвищеною харчовою цінністю, адже вони в процесі виробництва втрачають основний свій харчовий потенціал.

Метою дослідження $\epsilon$ розробка технології виробництва комбінованих круп $\mathrm{i}$ плющених продуктів із голозерних видів зерна вівса та ячменю, що дасть змогу отримати продукти $з$ підвищеною харчовою цінністю.

Матеріали і методи. Об'єкти дослідження - технологічні процеси переробки зерна в крупи та круп'яні продукти. Предмет досліджень: зерно голозерного вівса та голозерного ячменю, фізико-хімічні властивості сировини та готової продукції, структура та режими технологічного процесу виробництва круп і круп'яних продуктів.

Результати дослідження. У ході проведення досліджень визначено високий потенціал досліджуваного зерна голозерного вівса та голозерного ячменю для виробництва круп'яних продуктів. Встановлено, що голозерне зерно за своїми властивостями переважає плівчасте, при застосуванні більш м'яких режимів воднотеплової обробки та шліфування продукти, отримані з такого зерна, характеризуються підвищеною харчовою цінністю, що дає змогу говорити про доцільність застосування голозерного зерна як сировини для виробництва комбінованих зернових продуктів 3 підвищеною харчовою цінністю. Також розроблено структуру переробки голозерного вівса та голозерного ячменю в комбіновані продукти (рис. 1), яка включає в себе очищення зерна від домішок, водно-теплову обробку зерна, шліфування, сортування продуктів шліфування, водно-теплову обробку крупи, змішування, плющення підсушування, контроль готової продукції.

Враховуючи відмінності в характеристиках, особливо у формі зерна, переробку голозерного вівса та голозерного ячменю здійснюють без фракціонування на двох паралельних лініях. Зерно очищують від домішок і при необхідності (вологість зерна менше $12 \%$ ) направляють на етап водно-теплової обробки, де його зволожують підігрітою до $60^{\circ} \mathrm{C}$ водою до вологості не більше $14 \%$ та направляють на шліфування.

Етап шліфування для обох культур здійснюють за принципом інтенсивного стирання оболонок із застосуванням лущильно-шліфувальних машин типу ЗШН. Встановлено, що шліфування зерна голозерного вівса та голозерного ячменю одним потоком при більш м'яких режимах дає змогу отримувати шліфоване ядро 3 підвищеною харчовою цінністю - високим вмістом білка та $\beta$-глюканів, при цьому значення мікробіологічних показників та зольності суттєво не зростають порівняно 
3 традиційною технологією. Тому для виробництва комбінованих продуктів підвищеної харчової цінності шліфування передбачається проводити з використанням однієї шліфувальної системи. При цьому пом'якшення режиму досягається шляхом зменшення колової швидкості шліфувальних дисків.

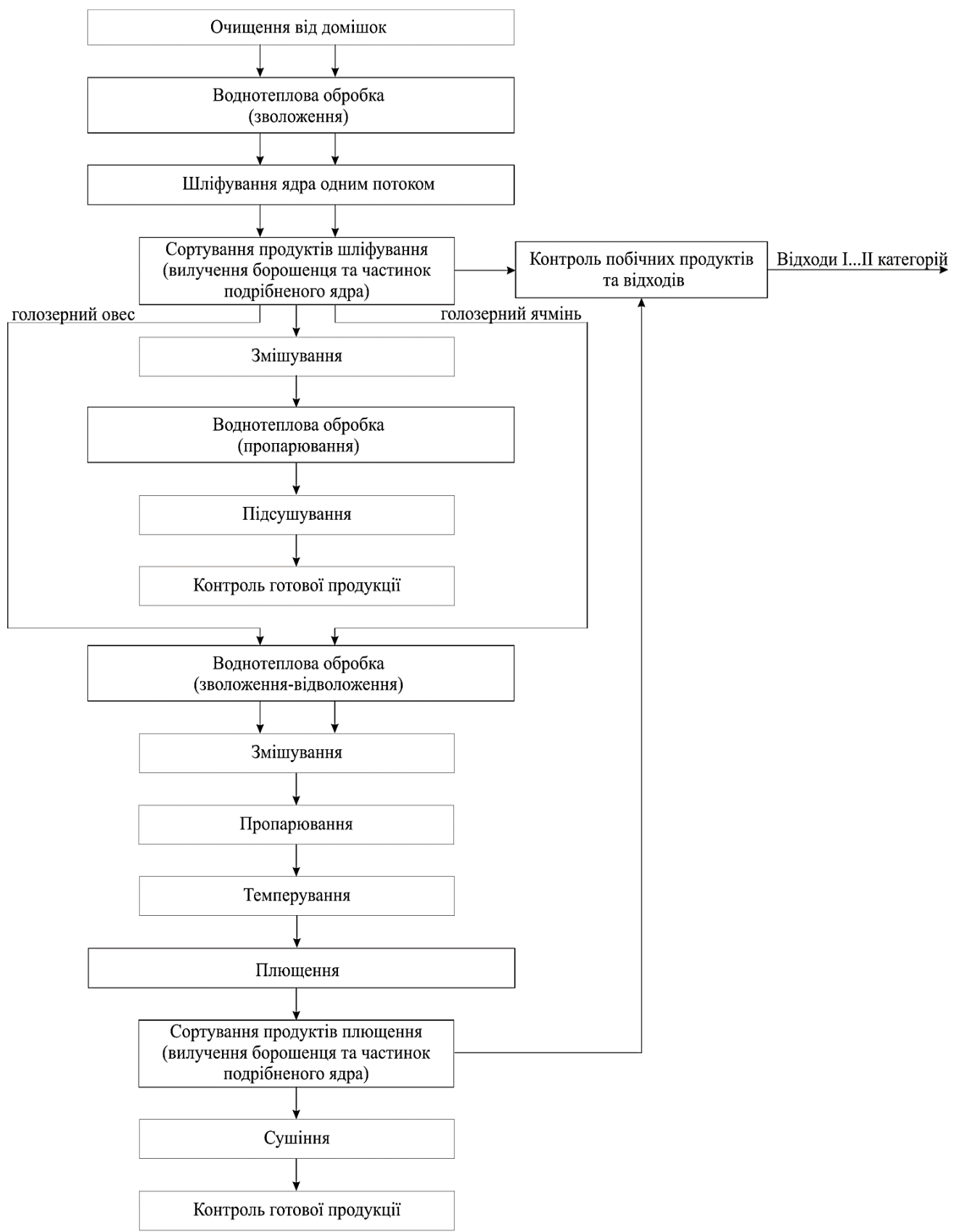

Рис. 1. Структурна схема виробництва комбінованих круп і плющених продуктів із голозерного вівса та голозерного ячменю 
Подальше зменшення колової швидкості шліфувальних дисків призведе до недостатнього зняття поверхневих шарів зерна при обробці на одній шліфувальній системі, що, відповідн,о викличе необхідність збільшення кількості шліфувальних систем до двох-трьох, що, у свою чергу, збільшить протяжність та енергоємність процесу. Збільшення колової швидкості шліфувальних дисків сприятиме більш інтенсивному зняттю поверхневих шарів зерна, що призведе до збільшення кількості побічних продуктів у вигляді частинок подрібненого ядра та борошенця та, відповідно, зменшення харчової цінності цілого ядра. Збільшення виходу побічних продуктів призведе до необхідності розширення етапу сортування продуктів шліфування за рахунок установлення додаткових сито-повітряних сепараторів та аспіраційних колонок.

У результаті шліфування зерна голозерного вівса та голозерного ячменю утворюється суміш, яка складається з цілого ядра, частинок подрібненого ядра та борошенця. Для іï розділення і вилучення цілого ядра суміш на першому етапі направляють у круп'яні розсійники, де проводять вилучення борошенця та частинок подрібненого ядра. При сортуванні продуктів шліфування у розсійниках встановлюють пробивні сита 1,8-1,6·20 мм, сходом яких вилучають ціле шліфоване ядро, прохід являє собою суміш частинок подрібненого ядра та борошенця. Розділення проводять на металотканих ситах 080-060 мм, проходом яких отримують борошенце, сходом - частинки подрібненого ядра. Шліфоване ядро додатково контролюють на залишки борошенця шляхом пропуску крізь одну систему повітряних сепаратоpiB.

На наступному етапі при виробництві суміші круп проводять змішування шліфованого ядра голозерного вівса та голозерного ячменю у заданих масових частках i направляють суміш на водно-теплову обробку. Основною метою цього етапу є зниження мікробіологічного обсіменіння на поверхні ядра та надання продукту характерних для споживачів властивостей. При цьому, як показали результати досліджень для забезпечення виробництва продукту із підвищеною харчовою цінністю, необхідно також пом'якшувати режими водно-теплової обробки. Враховуючи це, суміш шліфованого ядра направляють у пропарювач періодичної дії, де іiі пропарюють при тиску насиченої пари $0,05-0,15$ МПа протягом 2-4 хв. Такий режим забезпечує мінімальні зміни у хімічному комплексі зерна, не відбувається потемніння крупи, яке характерне для більш жорстких режимів ВТО, при цьому за органолептичними характеристиками (запахом та смаком) отриманий продукт повністю відповідає традиційним крупам. Після пропарювання ядро надходить на підсушування. Крупу підсушують до вологості $12-14 \%$ та направляють на контроль, який здійснюють на одній системі повітряних сепараторах, де проводять вилучення залишків борошенця. Перед фасуванням крупу обов’ язково контролюють на залишки металомагнітних домішок шляхом їі пропуску крізь магнітні сепаратори.

При виробництві суміші пластівців ціле ядро після шліфування надходить на водно-теплову обробку. Цей етап передбачає комбіновану структуру холодного і гарячого кондиціювання, основним призначенням якого є забезпечення пластичних властивостей ядра. Перед пропарюванням ядро голозерного вівса зволожують до вологості 15-17\% та направляють на відволоження, яке триває 2,0-3,0 год. Зерно голозерного ячменю зволожують до вологості $20-22 \%$ та відволожують протягом $2-4$ год. Після цього у заданих масових частках проводять формування суміші, яку направляють на пропарювання. Суміш перед плющенням пропарюють при тиску насиченої пари $0,10-0,15$ МПа протягом 4-5 хв та темперують протягом 7 хв. 
Плющення проводять на плющильних верстатах на рифлених валках. Плющення на рифлених валках забезпечує утворення мікротріщин на поверхні пластівців, що дасть змогу пришвидшити термін варіння отриманого продукту. Міжвальцьовий зазор при плющенні встановлюють 0,2-04 мм, що дасть змогу отримувати плющені продукти із підготовленого при більш м'яких режимах ВТО з органолептичними та фізичними характеристиками, які характерні для традиційних вівсяних та ячмінних пластівців.

Масова частка білка в ядрі голозерного вівса після пропарювання при застосуванні м'яких режимів (0,05-0,10 МПа) зменшується з 14,0-14,5\% до 13,0-13,8\%, збільшення тиску пари до 0,15 МПа призводить до зменшення вмісту білка з 13,1$13,5 \%$, Масова частка білка в шліфованому ядрі голозерного ячменю при досліджуваних режимах пропарювання складає 14,1-14,8\%. При виробництві плющеного ядра масова частка білка - $12-14 \%$ та $\beta$ глюканів - 4,0-5,5\%. Для шліфованого ядра голозерного ячменю масова частка цього компонента після пропарювання складає 5,4-5,8\%, в ядрі голозерного вівса $5,1-5,3 \%$.

Після плющення суміш пластівців просіюють для вилучення частинок подрібненого ядра та борошенця, яке утворюється в незначній кількості при плющенні. Просіювання проводять у круп'яному розсійнику, при цьому сходом сит 1,4·20 мм отримують основний продукт, який направляють на подальшу переробку, проходом цього сита і сходом металотканого сита 063 мм проводять вилучення частинок подрібненого ядра, проходом сита 063 вилучають борошенце. Отриману суміш пластівців підсушують на стрічкових сушарках до вологості $13-14 \%$ та направляють на магнітний контроль і фасування.

Висновки. Особливістю розробленої схеми є значне порівняно 3 існуючими технологіями виробництва аналогічних продуктів з ячменю та вівса скорочення технологічного процесу - відсутні енергоємні етапи лущення, сортування продуктів лущення, круповідділення, шліфування із застосуванням декількох систем, що дає змогу проводити повний цикл виробництва на заводах малої продуктивності. При цьому застосування як сировини голозерного вівса та голозерного ячменю при рекомендованих режимах збільшує вихід шліфованого та плющеного ядра в 1,51,7 раза порівняно з переробкою плівчастих культур. Отримані окремі продукти завдяки використанню м'яких режимів шліфування і воднотеплової обробки характеризуються високою харчовою цінністю - мають більшу частку білка та $\beta$-глюканiв.

\section{ЛІТЕРАТУРА}

1. Правила організації і ведення технологічного процесу на круп'яних заводах. - К., 1998. - $164 \mathrm{c}$.

2. Шутенко Є. I. Технологія круп'яного виробництва: навч. Посібник [Текст] / Є. І. Шутенко, С. М. Соц. - К.: Освіта України, 2010. - 272 с.

3. Pomeranz Y. Functional properties of food components [Text] / Y. Pomeranz - San Diego, CA: Academic Press, 1991. - 560 p.

4. Бутенко Л. И., Лигай Л. В. Исследования химического состава пророщенных семян гречихи, овса, ячменя и пшеницы // Фундаментальные исследования. - 2013. - № 4-5.

5. Karwowski Jan, and Robert F. Ferraro. "Process for the preparation of multiple grain flaked cereal." U.S. Patent No. 4,603,055. 29 Jul. 1986.

6. Seppo K. A. Method for preparing an oat product and a foodstuff enriched in the content of $\beta$-glucan [Text] / K. Seppo, et al. // [Електронний ресурс]. — Режим доступу: http://www.google.tl/ patents/WO2001026479A1?cl=en 
7. Способ производства многокомпонентных зерновых хлопьев Амирханов К. Ж., Асенова Б. К., Жаксыгулова Д. Д. № 30199, МПК А23L 1/00.

8. Способ производства сухой питательной смеси № 2156084, МПК А23L1/29, A23L1/10, Аюшеева О. Г.; Найдакова Ц. А.; Николаев С. М.; и др.

\title{
ПРОИЗВОДСТВО КРУП И ПЛЮЩЕНЫХ ПРОДУКТОВ ПРИ ПЕРЕРАБОТКЕ ЗЕРНА ГОЛОЗЕРНОГО ОВСА И ГОЛОЗЕРНОГО ЯЧМЕНЯ
}

\author{
С. М. Соц, И. О. Кустов, Ю. Я. Кузьменко \\ Одесская национальняа академия пищевы хтехнологий
}

В статье рассмотрены основные преимущества голозерного зерна овса и ячменя в сравнении с традиционными формами, что обусловливает пересмотр и научное обоснование структуры, режимов технологического процесса с расширением ассортимента и возможностью производства продуктов с повышенной пищевой ценностью.

Разработана структурная схема переработки голозерного овса и голозерного ячменя в комбинированные крупы и плющеные продукты, которая включает в себя очистку зерна от примесей, водно-тепловую обработку зерна, шлифовку, сортировку продуктов шлифования, водно-тепловую обработку крупы, смешивание, плющение, подсушивание и контроль готовой продукции.

Установлено, что применение голозерного овса и голозерного ячменя при рекомендуемых режимах позволяет увеличить выход шлифованного и плющеного ядра в 1,5-1,7 раза по сравнению с переработкой пленчатых культур.

Ключевые слова: голозерный овес, голозерный ячмень, технология производства, повышение пищевой ценности, упрощение технологического процесса. 